\title{
Effect of 19-Norandrostenololylaurate on Semen Characteristics of Colts
}

\author{
By E. Koskinen ${ }^{1}$, P. Marttila ${ }^{2}$ and T. Katila ${ }^{2}$ \\ ${ }^{1}$ Agricultural Research Centre, Equine Research, Ypäjä, and ${ }^{2}$ Animal Reproduction, Faculty of Veteri nary Med- \\ icine, University of Helsinki, Finland.
}

\begin{abstract}
Koskinen E., Marttila P., and T. Katila: Effect of 19-norandrostenololylaurate on semen characteristics of colts. Acta vet. scand. 1997, 38, 41-50. - The long-term effects of the anabolic steroid 19-norandrostenololylaurate on semen characteristics of Finnhorse colts were studied in 3 experiments. Semen was collected initially at 24 months of age and then twice a year. In experiment I, $500 \mathrm{mg}$ or $100 \mathrm{mg}$ of steroid per animal was given every 3 rd week from 12 or 16 months to 24 months of age. In colts treated with $500 \mathrm{mg}$ of anabolic steroid every $3 \mathrm{rd}$ week, azoospermia was observed in 3 out of 5 colts in the first semen collections, immediately after the end of treatment. The other 2 colts had low sperm numbers and a high percentage of proximal droplets in relation to control animals. The $100 \mathrm{mg}$ group was less affected by steroid treatment than the $500 \mathrm{mg}$ group. The seminal changes were observed to be reversible. All of the colts had spermatozoa in their ejaculates 4 months after the end of treatment. Two years after cessation of treatment, sperm numbers in treated animals exceeded those in the control group.

In experiment II, colts were treated from 7 months to 12 months of age with a dose of 1 $\mathrm{mg} / \mathrm{kg}$ every $3 \mathrm{rd}$ week or $0.3 \mathrm{mg} / \mathrm{kg}$ every week. The first semen collections took place 12 months after the last treatment. The animals treated with $0.3 \mathrm{mg} / \mathrm{kg}$ every week were less affected than those treated with $1 \mathrm{mg} / \mathrm{kg}$ every 3 rd week.

In experiment III, animals were treated from 3 months to 8 months of age, and the interval from the last treatment to the first semen collection was 16 months. There were no significant differences between the groups in any of the semen parameters examined. In the last semen collection, the control animals had numerically higher spermatozoal concentration and progressive motility and less dead sperm than the treated animals. It was concluded that the adverse effects of steroid treatment on semen characteristics were reversible, at least in the groups treated at age 7-25 months.
\end{abstract}

stallion; anabolic; steroid; sperm; numbers; morphology.

\section{Introduction}

Anabolic steroids have been recommended as adjunctive therapy to debilitated and anaemic horses to stimulate positive nitrogen balance, appetite and erythropoiesis (Maher et al. 1983, Davis 1981). Anabolic steroids are used also in healthy horses to obtain maximal development and athletic potential in races, performances and shows (Maher et al. 1983). However, data confirming desired effects in horses is lacking or controversial. Boldenone undecylenate injections $(1.1 \mathrm{mg} / \mathrm{kg}$ every 3rd week) did not accelerate growth and, with the exception of plasma protein, did not change blood chemistry values in healthy 2-year-old geldings (Burke et al. 1981). Anabolic steroid treatments had no effect on weight gain or on height at withers in yearling mares (Maher et al. 1983). Weekly 
nandrolone phenylpropionate injections (400 $\mathrm{mg}$ ) had no effect on body weight, nitrogen retention or plasma urea in healthy mature geldings (Snow et al. 1982a). No such effects could be shown either when the geldings underwent training, and no evidence of improved racing performance due to anabolic steroid administration was observed (Snow et al. 1982b).

On the other hand, adverse effects such as decreased testicular size and depressed spermatogene sis (Squires et al. 1982, Blanchard et al. 1983) and aggressive stallion-like behaviour in mares (Maher et al. 1983) and in geldings (Burke et al. 1981) are well documented. The negative effects on spermatogenesis are reversible in sexually mature stallions (Squires et al. 1981), but this has not been confirmed in young animals. Boldenone undecylenate injections every $3 \mathrm{rd}$ week to colts between 7 and 11 months of age significantly reduced testis and parenchyma weight and the number of sperm (Jackson et al. 1991). However, since the animals were castrated immediately after treatment, it is uncertain wether the changes were reversible.

The use of anabolic steroids in animals or human athletes is illegal in many countries, except therapeutically, e.g. after severe operations. Because anabolic steroids are used in the equine industry to obtain maximal performance, knowledge of any untoward side-effects on reproduction is important (Jackson et al. 1991). Often this type of drug treatment is initiated at an early age and continued for lengthy periods without regard to the future breeding soundness of the animal (Maher et al. 1983). The aim of this study was to investigate the effects of anabolic steroid treatment on semen characteristics of colts of different ages and to follow the animals after cessation of treatment to determine whether effects were reversible. The effects of the anabolic steroid on the nutrition and growth of foals have been previously reported (Saastamoinen \& Koskinen 1993).

\section{Materials and methods}

The animals used were Finnhorse colts raised for trotting and riding. Finnhorse is a coldblood breed, the adult horse weighing 500-600 $\mathrm{kg}$. The colts were not trained but started on light exercise at 3 years of age. They were kept on pasture from June to September. During winter they were in an unheated barn with free access to a paddock. Three experiments were carried out: the first starting in autumn, the second at the start of the following year, and the third in autumn 2 years later. All colts in the 3 experiments were born in May or June except for 3 born in April, July and August. The anabolic steroid used was an injectable 19-norandrostenololylaurate preparation (Laurabolin vetR, Intervet International B.V., 5830 AA Boxmeer, The Netherlands). The manufacturer recommends a dose of 100-200 mg every 3 weeks for adult horses, e.g. to aid in recovery after a major operation. The recommended dose corresponds to a dose of $0.2-0.4 \mathrm{mg} / \mathrm{kg}$ for a $500 \mathrm{~kg}$ horse. Because people are said to use much higher doses of ste roids for doping than the therapeutical dose, the higher dose chosen in experiment I was $500 \mathrm{mg}$ for colts which weighed roughly $400 \mathrm{~kg}$ during the treatment period. The dose in experiments II and III was calculated in $\mathrm{mg} / \mathrm{kg}$ of body weight. The treatment period varied between 5 and 8 months. The treatment protocols in experiments I-III are shown in Table 1. One untreated colt was removed from the control group in experiment I due to abnormally high sperm concentrations (sperm stasis) and one untreated colt was removed from experiment II because initial ejaculates were not collected.

Semen was collected using an open-ended artificial vagina ${ }^{1}$. All fractions were taken. Collection was started at age 24 months and continued

\footnotetext{
${ }^{1}$ Krakow model, Poland.
} 
Table 1. Treatment of colts with 19-norandrostenololylaurate.

\begin{tabular}{cccccc}
\hline Experiment & $\begin{array}{c}\text { Number } \\
\text { of } \\
\text { animals }\end{array}$ & $\begin{array}{c}\text { Age at } \\
\text { start of } \\
\text { treatment } \\
\text { (months) }\end{array}$ & $\begin{array}{c}\text { Age at } \\
\text { end of } \\
\text { treatment } \\
\text { (months) }\end{array}$ & $\begin{array}{c}\text { Dose } \\
\text { level } \\
\text { val }\end{array}$ & $\begin{array}{c}\text { Dosage } \\
\text { inter- }\end{array}$ \\
\hline I & 5 & - & - & Untreated & - \\
& 5 & $12-16$ & 24 & $100 \mathrm{mg}$ & 3 weeks \\
II & 5 & $12-16$ & 24 & $500 \mathrm{mg}$ & 3 weeks \\
& 5 & - & - & Untreated & - \\
III & 4 & 7 & 12 & $1 \mathrm{mg} / \mathrm{kg}$ & 3 weeks \\
& 4 & - & - & $0.3 \mathrm{mg} / \mathrm{kg}$ & 1 week \\
& 3 & - & - & Untreated & - \\
\hline
\end{tabular}

for 2 years in Experiments I and III. For technical reasons, semen collection continued for only 1 year in Experiment II. Semen was collected every other day in May or June, and in September or November. Each animal was sampled 2-8 times during the collection period. Mean values of semen parameters per period were calculated for each colt. This data was analysed statistically and plotted graphically.

After measurement of gel-free volume, sperm motil ity was evaluated at $\times 200$ magnification on a warm stage at $37^{\circ} \mathrm{C}$. Sperm concentrations were determined using a Bürker chamber. The morphology of 100 sperm cells was evaluated on eosin-nigrosin stained slides using a phase contrast microscope. If several abnormalities were detected in the same cell, only one was recorded in the following order: head, neck, midpiece and tail. Live-dead ratios of 200 sperm cells were counted on eosin-nigrosin stained slides at $\times 1000$ magnification, using an oil-immersion microscope. Frequencies of proximal droplets were calculated in 200 sperm cells fixed in buffered formol saline (BFS) ${ }^{2}$. All se-

2 BFS: Na2HPO4 $4.93 \mathrm{~g}$; KH2PH4 $2.54 \mathrm{~g}$; 38\% formaldehyde $125 \mathrm{ml} ; \mathrm{NaCl} 5.41 \mathrm{~g}$; distilled water q.s. $1000 \mathrm{ml}$ men analyses were carried out by the same technician.

\section{Statistical analyses}

Two groups were compared at different time points using t-tests for independent samples. Three groups were compared using analysis of variance followed by the Tukey test. Group differences in changes during trials were analysed using repeated-measures analysis of variance and paired-sample t-tests.

\section{Results}

In all experiments, semen quality as indicated by number of sperm $/ \mathrm{ml}$ and percentage of progressive motility and proximal droplets was poor at age 24 months in animals treated with a high dose of steroid every 3rd week. Two years after the last treatment, the semen quality of treated animals was equal to controls in experiment I, slightly better in experiment II and slightly poorer in experiment III (Tables 2-4).

\section{Experiment I}

Number of spermatozoa per ejaculate during the study is shown in Fig. 1. At the end of the treatment period, 3 of the 5 colts treated with $500 \mathrm{mg}$ every $3 \mathrm{rd}$ week were azoospermic. In 
Table 2. Analysis of ejaculates at age 24,36 , and 48 months in untreated colts and in colts treated every 3rd week with $100 \mathrm{mg}$ or $500 \mathrm{mg}$ of 19 -norandrostenololylaurate from 12 or 16 months to 24 months of age.

\begin{tabular}{|c|c|c|c|c|}
\hline & $\begin{array}{l}\text { Number } \\
\text { of } \\
\text { ejaculates }\end{array}$ & $\begin{array}{l}\text { Control } \\
\text { group }\end{array}$ & $\begin{array}{c}100 \mathrm{mg} \\
\text { every } \\
\text { 3rd week }\end{array}$ & $\begin{array}{c}500 \mathrm{mg} \\
\text { every } \\
\text { 3rd week }\end{array}$ \\
\hline $\begin{array}{l}\text { Number of animals } \\
\text { at age } 24 \text { months }\end{array}$ & & 5 & 5 & 2(a) \\
\hline Total sperm per ejaculate $\left(\times 10^{6}\right)$ & 8 & 5202 & 3342 & 992 \\
\hline Sperm $/ \mathrm{ml}\left(\times 10^{6}\right)$ & 8 & 255 & 115 & $18^{*}$ \\
\hline Gel free volume (ml) & 8 & 32.8 & 28.4 & 43.5 \\
\hline Progressive motility (\%) & 8 & 40.1 & 45.2 & 24.6 \\
\hline Live normal sperm (\%) & 8 & 47.3 & 53.0 & 49.6 \\
\hline Live abnormal sperm (\%) & 8 & 52.5 & 46.5 & 49.6 \\
\hline Proximal droplets (\%) & 8 & 8.2 & 16.1 & $38.6^{*}$ \\
\hline Dead sperm (\%) & 8 & 26.5 & 23.1 & 41.2 \\
\hline $\begin{array}{l}\text { Number of animals } \\
\text { at age } 36 \text { months }\end{array}$ & & 5 & 5 & 5 \\
\hline Total sperm per ejaculate $\left(\times 10^{6}\right)$ & 3 & 9139 & 7967 & 9148 \\
\hline $\mathrm{Sperm} / \mathrm{ml}\left(\times 10^{6}\right)$ & 3 & 224 & 190 & 157 \\
\hline Gel free volume $(\mathrm{ml})$ & 3 & 56.3 & 50.3 & 63.0 \\
\hline Progressive motility (\%) & 3 & 19.7 & 32.0 & 27.7 \\
\hline Live normal sperm (\%) & 3 & 50.9 & 43.7 & 58.2 \\
\hline Live abnormal sperm (\%) & 3 & 48.6 & 40.0 & 41.6 \\
\hline Proximal droplets (\%) & 3 & 3.0 & 3.5 & 2.4 \\
\hline Dead sperm (\%) & 3 & 22.9 & 29.5 & 25.9 \\
\hline $\begin{array}{l}\text { Number of animals } \\
\text { at age } 48 \text { months }\end{array}$ & & 5 & 5 & 5 \\
\hline Total sperm per ejaculate $\left(\times 10^{6}\right)$ & 2 & 8246 & 10348 & 17718 \\
\hline $\mathrm{Sperm} / \mathrm{ml}\left(\times 10^{6}\right)$ & 2 & 157 & 135 & 189 \\
\hline Gel free volume (ml) & 2 & 64.5 & 88.8 & 104.8 \\
\hline Progressive motility (\%) & 2 & 39.0 & 40.0 & 48.0 \\
\hline Live normal sperm (\%) & 2 & 63.4 & 73.6 & 70.1 \\
\hline Live abnormal sperm (\%) & 2 & 36.4 & 26.5 & 29.8 \\
\hline Proximal droplets (\%) & 2 & 0.7 & 0.8 & 0.5 \\
\hline Dead sperm (\%) & 2 & 39.5 & 31.3 & 33.0 \\
\hline
\end{tabular}

(a) Three azoospermic animals are not included in the calculations at this time point

* Different from control group, $\mathrm{p}<0.05$.

the other 2 colts, mean sperm numbers per ejaculate were low (Table 2) compared with sperm numbers in the control group $(\mathrm{p}<0.01)$. Four months later, all of the treated animals had spermatozoa in their ejaculate. Twenty-four months later, sperm numbers were higher in the treated colts than in the control colts $(\mathrm{p}<0.05)$. The 100 mg group was less affected by the steroid than the $500 \mathrm{mg}$ group. No statistically significant difference was found in sperm numbers between the $100 \mathrm{mg}$ group and the control group. Other results from semen analysis are 
Table 3. Analysis of ejaculates at age 24 and 36 months in untreated colts and in colts treated with $0.3 \mathrm{mg} / \mathrm{kg}$ every week or with $1 \mathrm{mg} / \mathrm{kg}$ every $3 \mathrm{rd}$ week of 19 -norandrostenololylaurate from 7 months to 12 months of age.

\begin{tabular}{lcccc}
\hline & $\begin{array}{c}\text { Number } \\
\text { of } \\
\text { ejaculates }\end{array}$ & $\begin{array}{c}\text { Control } \\
\text { group }\end{array}$ & $\begin{array}{c}0.3 \mathrm{mg} / \mathrm{kg} \\
\text { every } \\
\text { week }\end{array}$ & $\begin{array}{c}1 \mathrm{mg} / \mathrm{kg} \\
\text { every } \\
\text { 3rd week }\end{array}$ \\
\hline Number of animals at age 24 months & & 5 & 4 & 4 \\
Total sperm per ejaculate $\left(\times 10^{6}\right)$ & 3 & 5619 & 3635 & 1422 \\
Sperm/ml $\left(\times 10^{6}\right)$ & 3 & 188 & 162 & 37 \\
Gel free volume (ml) & 3 & 34.5 & 31.1 & 47.3 \\
Progressive motility (\%) & 3 & 21.9 & 32.5 & 18.6 \\
Live normal sperm (\%) & 3 & 55.3 & 53.8 & 43.8 \\
Live abnormal sperm (\%) & 3 & 44.7 & 45.6 & 55.3 \\
Proximal droplets (\%) & 3 & 6.3 & 4.5 & $16.8 *$ \\
Dead sperm (\%) & 3 & 27.6 & 22.6 & 32.8 \\
Number of animals at age 36 months & & 5 & 4 & 4 \\
Total sperm per ejaculate $\left(\times 10^{6}\right)$ & 2 & 13297 & 8069 & 17169 \\
Sperm/ml ( $\left.\times 10^{6}\right)$ & 2 & 293 & 163 & 176 \\
Gel free volume (ml) & 2 & 65.8 & 60.6 & 96.6 \\
Progressive motility (\%) & 2 & 25.5 & 43.8 & 40.0 \\
Live normal sperm (\%) & 2 & 64.3 & 63.8 & 68.9 \\
Live abnormal sperm (\%) & 2 & 37.6 & 38.1 & 33.4 \\
Proximal droplets (\%) & 2 & 6.6 & 7.1 & 8.9 \\
Dead sperm (\%) & 2 & 40.1 & 27.9 & 36.8 \\
\hline
\end{tabular}

* Different from control group, $\mathrm{p}<0.05$.

shown in Table 2. In the first semen collections, the percentage of proximal droplets was highest in the $500 \mathrm{mg}$ group and lowest in the con trol group $(\mathrm{p}<0.05)$ but in collections 4 months later, the difference was no longer significant. Also the percentage of dead spermatozoa was highest in the $500 \mathrm{mg}$ group in the first semen collections, but the difference disappeared in later collections.

\section{Experiment II}

In all first ejaculates from the colts 12 months after the last treatment, spermatozoa were present, but mean sperm numbers per ejaculate were lower in the group treated with $1 \mathrm{mg} / \mathrm{kg}$ every 3 rd week in relation to the control group, $\mathrm{p}<0.05$, (Fig. 2). Sperm numbers were lower at all time points in the $0.3 \mathrm{mg} / \mathrm{kg}$ every week group than in the control group, but the difference was not statistically significant. Two years after the last treatment, sperm numbers were highest in the group that had been treated with $1 \mathrm{mg} / \mathrm{kg}$ every $3 \mathrm{rd}$ week, but this difference was not statistically significant in relation to control group. In the first semen collections, the percentage of proximal droplets was highest in the group of animals treated with $1 \mathrm{mg} / \mathrm{kg}$ every 3 rd week ( $<<0.05$ in relation to control group) (Table 3). Four months later, statistically significant differences between the groups were no longer present.

\section{Experiment III}

In these colts, the interval from the final treat- 
Table 4. Analysis of ejaculates at age 24, 36, and 48 months in untreated colts and in colts treated every 3 rd week with $1 \mathrm{mg} / \mathrm{kg}$ of 19 -norandrostenololylaurate from 3 months to 8 months of age.

\begin{tabular}{|c|c|c|c|}
\hline & $\begin{array}{c}\text { Number } \\
\text { of } \\
\text { ejaculates }\end{array}$ & $\begin{array}{l}\text { Control } \\
\text { group }\end{array}$ & $\begin{array}{c}1 \mathrm{mg} / \mathrm{kg} \\
\text { every } \\
\text { 3rd week }\end{array}$ \\
\hline Number of animals at age 24 months & & 3 & 3 \\
\hline Total sperm per ejaculate $\left(\times 10^{6}\right)$ & 3 & 7186 & 4676 \\
\hline Sperm/ml $\left(\times 10^{6}\right)$ & 3 & 274 & 165 \\
\hline Gel free volume $(\mathrm{ml})$ & 3 & 36.9 & 29.0 \\
\hline Progressive motility (\%) & 3 & 30.0 & 25.6 \\
\hline Live normal sperm (\%) & 3 & 64.0 & 55.9 \\
\hline Live abnormal sperm (\%) & 3 & 35.9 & 44.0 \\
\hline Proximal droplets (\%) & 3 & 12.0 & 14.0 \\
\hline Dead sperm (\%) & 3 & 23.7 & 27.7 \\
\hline Number of animals at age 36 months & & 3 & 3 \\
\hline Total sperm per ejaculate $\left(\times 10^{6}\right)$ & 3 & 10701 & 8411 \\
\hline Sperm $/ \mathrm{ml}\left(\times 10^{6}\right)$ & 3 & 246 & 212 \\
\hline Gel free volume $(\mathrm{ml})$ & 3 & 54.2 & 56.3 \\
\hline Progressive motility (\%) & 3 & 41.1 & 32.7 \\
\hline Live normal sperm (\%) & 3 & 68.9 & 59.2 \\
\hline Live abnormal sperm & 3 & 31.1 & 40.8 \\
\hline Proximal droplets (\%) & 3 & 2.5 & 4.1 \\
\hline Dead sperm (\%) & 3 & 58.0 & 55.6 \\
\hline Number of animals at age 48 months & & 3 & 3 \\
\hline Total sperm per ejaculate $\left(\times 10^{6}\right)$ & 3 & 7480 & 8370 \\
\hline Sperm $/ \mathrm{ml}\left(\times 10^{6}\right)$ & 3 & 240 & 110 \\
\hline Gel free volume (ml) & 3 & 34.2 & 84.4 \\
\hline Progressive motility (\%) & 3 & 42.2 & 30.0 \\
\hline Live normal sperm (\%) & 3 & 72.0 & 67.1 \\
\hline Live abnormal sperm (\%) & 3 & 28.0 & 32.4 \\
\hline Proximal droplets (\%) & 3 & 3.5 & 5.2 \\
\hline Dead sperm (\%) & 3 & 27.9 & 38.2 \\
\hline
\end{tabular}

ment to the first semen collection was 16 months. Ejaculates from all of the colts contained spermatozoa (Fig. 3). Numbers of spermatozoa per ejaculate were slightly, but not significantly, lower in the treated group than in the control group during follow-up (Table 4). The quality of ejaculates was slightly poorer in the treated group compared with the untreated group from start to end of follow-up, except for total number of sperm at age 48 months.

\section{Discussion}

In the experiments reported here, semen was collected 2-8 times every other day during the collection period. Because this collection procedure does not allow the determination of daily sperm output (DSO), our sperm numbers per ejaculate are probably higher than DSO would have been. However, the number of collections was similar in all groups at different collection periods, thus allowing comparison between treated and untreated groups. 


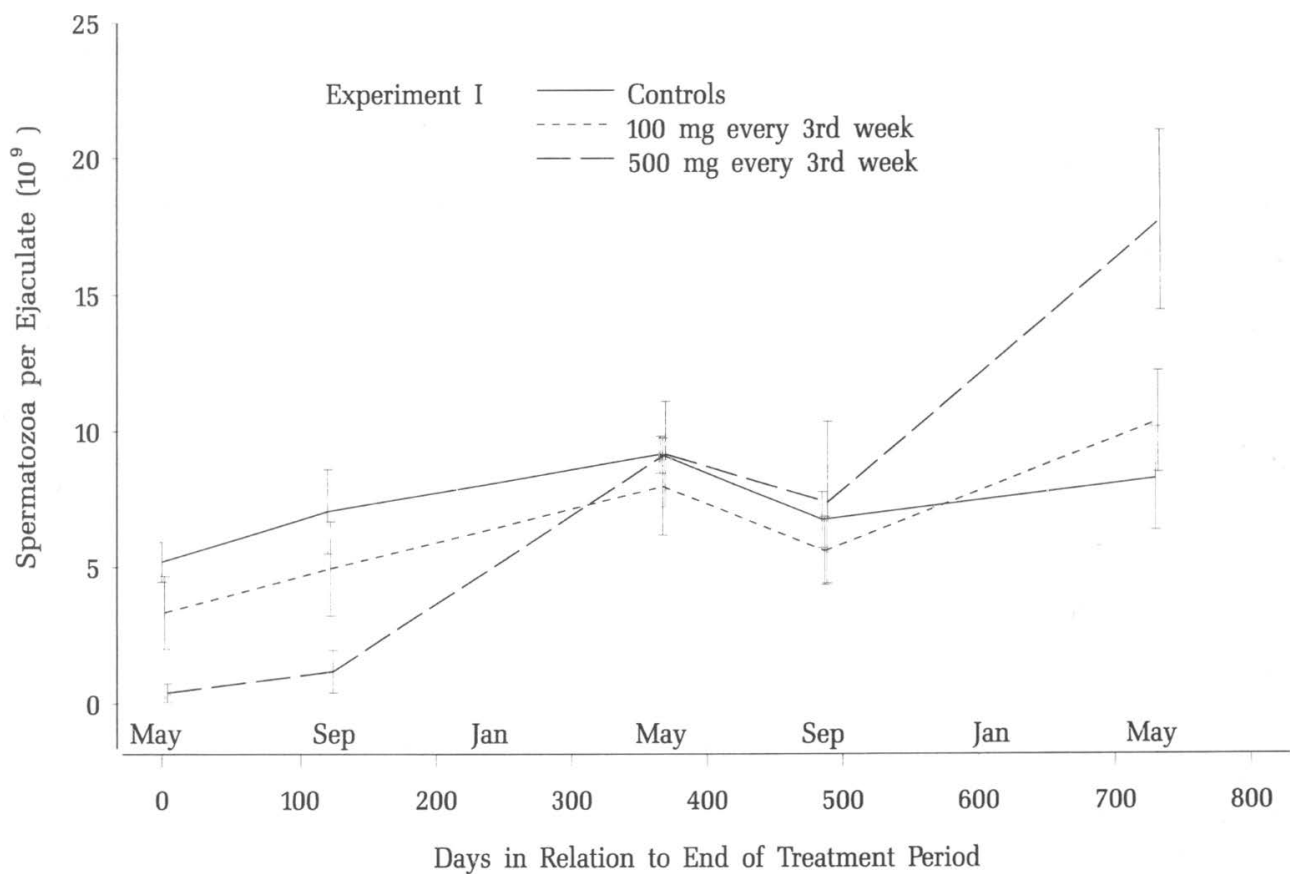

Figure 1. Mean \pm SEM of total sperm $\left(10^{9}\right)$; ejaculates obtained from untreated colts, or colts treated with $100 \mathrm{mg}$ or $500 \mathrm{mg}$ of 19-norandrostenololylaurate every 3rd week from 12 or 16 months to 24 months of age.

In experiment I, administration of 19-norandrostenololylaurate decreased numbers of spermatozoa shortly after treatment. This finding is in accordance with that in an earlier study (Squires et al. 1982), in which numbers of spermatozoa were considerably reduced after 15week treatments with nandrolone decanoate and, to some extent, boldenone undecylenate.

In experiment II, the number of spermatozoa per ejaculate in the first semen collections in the group receiving $1 \mathrm{mg} / \mathrm{kg}$ of steroid every 3rd week was $25 \%$ of that in the untreated animals. This finding is comparable to that reported by Jackson et al. (1991), who treated colts of similar age to these in our experiment with 2.2 $\mathrm{mg} / \mathrm{kg}$ boldenone undecylenate every 3rd week starting between 7 and 11 months of age and ending 16 months later. In their study, the num- ber of spermatozoa per ejaculate at the end of the treatment period was about $0.01 \%$ of that in the control group. However, we treated our colts for only 5 months, between ages 7 and 12 months and the interval from end of treatment to semen collection was 12 months. By that time some recovery of testicular function had probably occurred.

In experiment III, the number of spermatozoa per ejaculate was only slightly affected by steroid treatment. Because the foals were treated between 3 and 8 months of age, the interval from final treatment to first semen collection was long (16 months), with the result that no immediate effects could be observed. Either there were no effects, or they were minor, or the immediate effects were reversible.

The restoration of spermiogenesis after the de- 


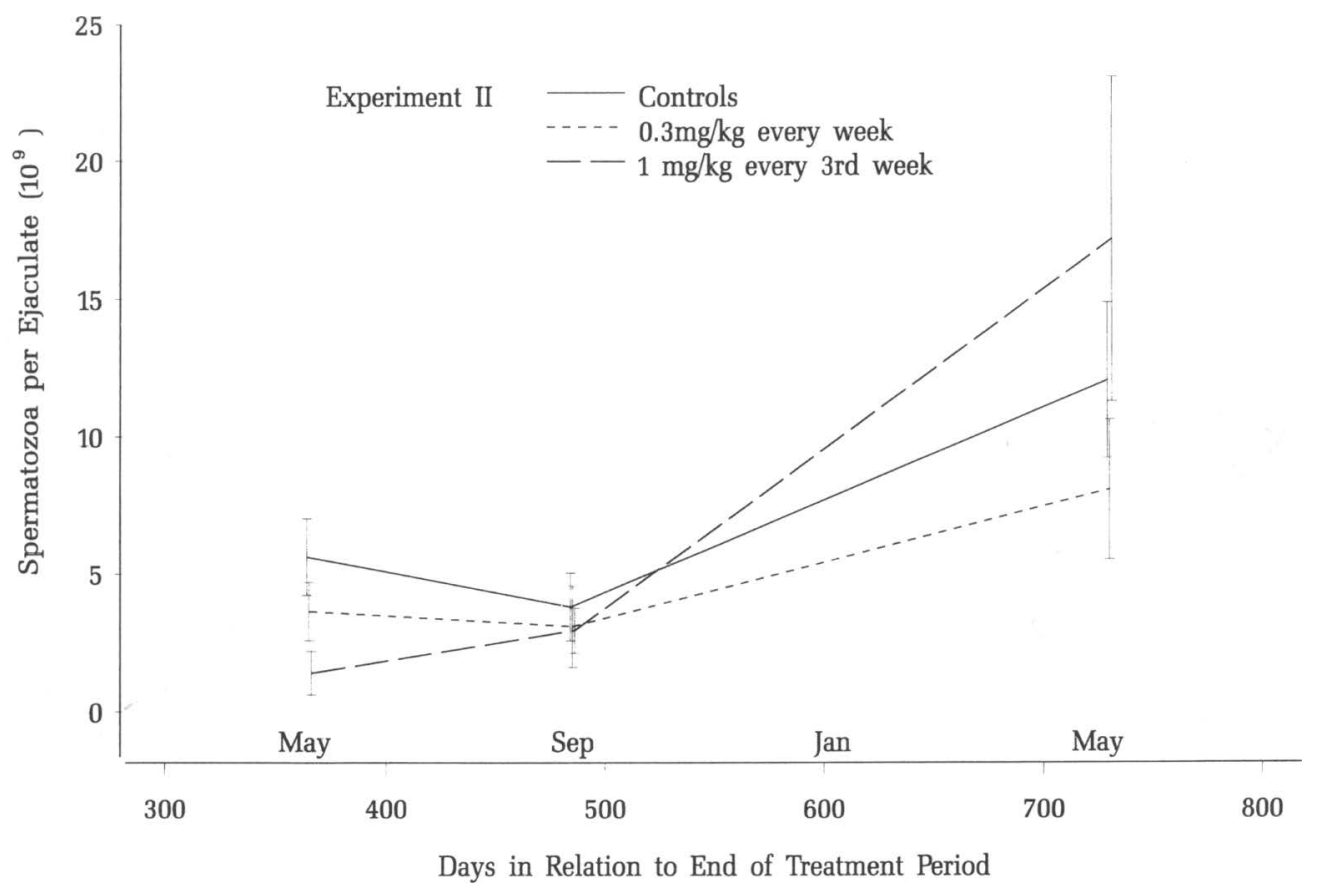

Figure 2. Mean $\AA$ SEM of total sperm $\left(10^{9}\right)$; ejaculates obtained from untreated colts, or colts treated with $0.3 \mathrm{mg} / \mathrm{kg}$ every week or colts treated with $1 \mathrm{mg} / \mathrm{kg}$ every $3 \mathrm{rd}$ week of 19-norandrostenololylaurate from 7 to 12 months of age.

pression resulting from anabolic steroid administration, which was seen in experiments I and II, is in agreement with the findings of Squires et al. (1981). In their study, stallions were followed-up for 3 months after testosterone treatment. By the end of the observation period the treated stallions did not differ from the controls. Groups that had received $500 \mathrm{mg}$ of steroid every $3 \mathrm{rd}$ week in experiment $\mathrm{I}$ or $1 \mathrm{mg} / \mathrm{kg}$ in experiment II had higher sperm numbers per ejaculate 2 years after treatment than the control groups. This can be a normal variation among horses in a small material. However, a similar "rebound phenomenon" - an increase in sperm numbers following cessation of testosterone administration - occurs in oligospermic men (Davis 1981). Testosterone is used in oligospermic human males to suppress already low sperm numbers. On withdrawal of testosterone, sperm numbers often increase (Davis 1981). No "rebound" increase in sperm numbers was seen in experiment III by age 4 years.

In experiment II, the different frequency of administration (weekly vs. every 3 rd week) had a different effect on ejaculates. Treatment at weekly intervals had less effect on the quality of ejaculate and on sperm numbers than treatment every 3rd week, and no "rebound" increase in sperm numbers was detected. The half life of 19-norandrostenololy-laurate in horses is 26 days (Pösö 1995). Serum steroid concentration is presumably more constant after weekly injections, and levels may not be as harmful as the higher peaks following injection of a threefold dose every 3rd week. The same phenomenon has been reported by Blanchard et al. (1983): 


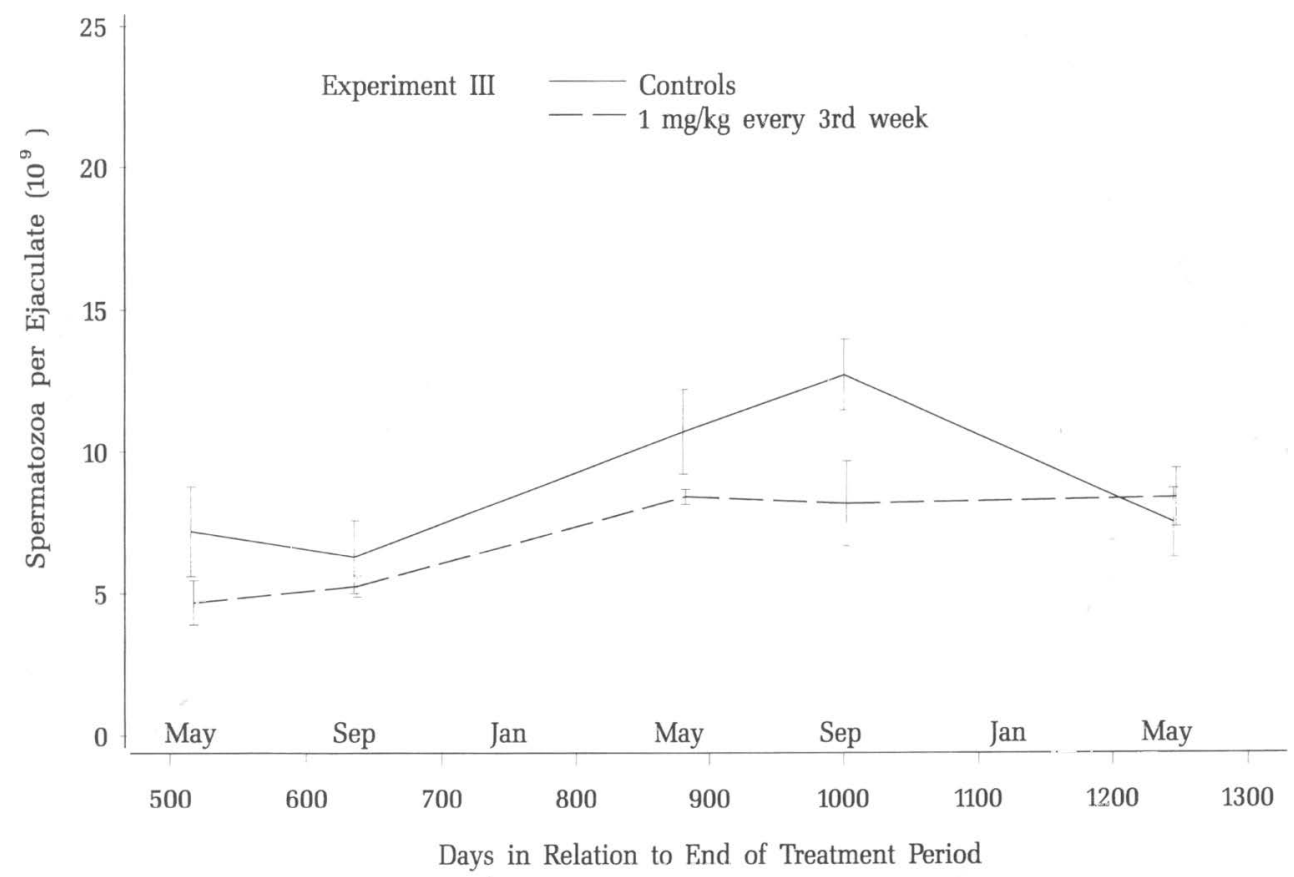

Figure 3. Mean $\AA$ SEM of total sperm $\left(10^{9}\right)$; ejaculates obtained from untreated colts or colts treated with $1 \mathrm{mg} / \mathrm{kg}$ every 3 rd week of 19 -norandrostenololylaurate from 3 to 8 months of age.

weekly injections of $0.55 \mathrm{mg} / \mathrm{kg}$ stanozolol did not have adverse effects on daily sperm production, whereas every 3rd week injections of 1.1 $\mathrm{mg} / \mathrm{kg}$ did.

The sperm quality, if limited to percentage of normal and abnormal spermatozoa in the ejaculate, was good in treated groups in experiment I during follow-up. This is comparable with observations of colts of similar age by Carson \& Thompson (1979), who found no effect of boldenone undecylenate treatment on the morphology of spermatozoa (collected from the vas deferens). In the first semen collections in groups treated with $1 \mathrm{mg} / \mathrm{kg}$ every 3rd week in experiments II and III, morphological abnormalities were found more often than in the control group. Findings in experiment II are in agreement with observations by Jackson et al.
(1991) who, using colts of similar age as our colts in experiment II, found an increase in abnormal sperm and decrease in normal sperm after anabolic steroid treatment. In experiments I and II, the percentage of proximal droplets was high in the first ejaculates. This indicates some disturbances in maturation of the spermatozoa. The effect of anabolic steroids using dose levels reported here would seem to be reversible. Recovery occurred faster if older colts were treated. The animals used in our experiments were castrated at 4 years of age. It is therefore not known whether the recovery of testicular function or the "rebound" increase observed in sperm numbers after anabolic treatment was permanent or transient. In addition, no breeding trials were done and the fertility of the treated colts therefore not studied. 


\section{References}

Blanchard TL, Elmore RG, Youngquist RS, Loch WE, Hardin DK, Bierschwal CJ, Ganjam VK, Balke $J M$, Ellersieck MR, Dawson LJ, Miner WS: The effects of stanozolol and boldenone undecylenate on scrotal width, testis weight, and sperm production in pony stallions. Theriogenology, 1983, 20, 121-131.

Burke PR, Potter GD, McMullan WC, Kreider JL, Dutson TR, Herring DS: Physiological effects of an anabolic steroid in the growing horse. Proc. 7th Eq. Nutr. Physiol. Symp., 1981, 161-164.

Carson RL, Thompson FN: Effects on an anabolic steroid on the reproductive tract in the young stallion. J. Eq. Med. Surg., 1979, 3, 221-224.

Davis LE: Anabolic steroids in the horse. J. Amer. vet. med. Ass., 1981, 179, 278-280.

Jackson AE, Skelton $K V$, Dowsett KF: Effects of anabolic steroid administration on the morphology of the colt testis. J. Reprod. Fert. Suppl., 1991, 44, 672-673.

Maher JM, Squires EL, Voss JL, Shideler RK: Effect of anabolic steroids on reproductive function of young mares. J. Amer. vet. med. Ass., 1983, 5 , 519-524.

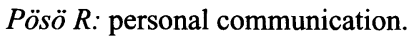

Saastamoinen M, Koskinen E: Influence of quality of dietary protein supplement and anabolic steroids on muscular and skeletal growth of foals. Anim. Prod., 1993, 56, 135-144.

Snow DH, Munro CD, Nimmo MA: Effects of nandrolone phenylpropionate in the horse: (1) Resting animal. Eq. Vet. J., 1982, 14, 219-223a.

Snow DH, Munro CD, Nimmo MA: Effects of nandrolone phenylpropionate in the horse: (2) General effects in animals undergoing training. Eq. Vet. J., 1982, 14, 224-228b.

Squires EL, Berndtson WE, Hoyer JH, Pickett BW, Wallach SJR: Restoration of reproductive capacity of stallions after suppression with exogenous testosterone. J. Anim. Sci., 1981, 53, 1351-1359.

Squires EL, Todter GE, Berndtson WE, Pickett BW: Effect of anabolic steroids on reproductive function of young stallions. J. Anim. Sci., 1982, 3, 576-582.

\section{Sammanfattning \\ Inverkan av 19-norandrostenololylaurat på sädes- vätskan hos hingstföl.}

Långtidsinverkan av den anabola steroiden 19-norandrostenololylaurat på sädesvätskans egenskaper hos Finlandshästens föl undersöktes i 3 experiment. Uppsamlingen av sädesvätska inleddes då fölen var i en ålder av 2 år och upprepades därefter två gånger om året. I experiment I fick varje djur en injektion av anabola steroiden $500 \mathrm{mg}$ eller $100 \mathrm{mg}$ på var tredje vecka från 12 eller 16 månaders ålder tills djuret var 24 månader. Tre av de 5 hingstföl som behandlats med $500 \mathrm{mg}$ var tredje vecka hade azoospermi redan vid den första uppsamlingen av sädesvätska, d.v.s. omedelbart efter att den protokollsenliga behandlingen avslutats. De 2 andra hingstföl hade låga antal spermier och hög procent av proximala droppar jämfört med kontrolldjuren. Gruppen som behandlade med $100 \mathrm{mg}$ påverkades mindre av steroidbehandlingen än $500 \mathrm{mg}$ :s gruppen. Förändringarna i sädesvätskan var reversibla och alla fölen hade spermier i ejakulatet 4 månader efter avslutad behandling. Två år efter att behandlingen avslutats översteg antalet spermier hos de behandlade djuren antalet spermier i kontrollgruppen.

I experiment II behandlades hingstfölen från och med 7 månaders ålder till 12 månaders ålder. Den anabola steroiden injiserades $i$ en dos på $1 \mathrm{mg} / \mathrm{kg}$ var tredje vecka eller $0.3 \mathrm{mg} / \mathrm{kg}$ varje vecka. Den första uppsamlingen av sädesvätska skedde 12 månader efter den sista injektionen. De djur som behandlats med $0.3 \mathrm{mg} / \mathrm{kg}$ varje vecka uppvisade mindre påverkan vad gäller spermietalet än djuren som behandlats med $1 \mathrm{mg} / \mathrm{kg}$ var tredje vecka.

I experiment III behandlades djuren från och med 3 månaders ålder till 8 månaders ålder, och tidsperioden från den sista steroiddosen till den första uppsamlingen av sädesvätska var 16 månader. Det förelåg inga signifikanta skillnader mellan grupperna $\mathrm{i}$ någon av de undersökta sädesvätskans parameter. I det sista provet hade kontrolldjuren numeriskt högre spermiekoncentration och progressiv motilitet och färre döda spermier än djuren som behandlats. Sammanfattningsvis kan konstateras att den negativa inverkan av steroidbehandlingen på sädesvätskan var reversibla, åtminstone bland föl som behandlats i en ålder av 7-25 månader.

\section{(Received February 24, 1996; accepted November 6, 1996).}

Reprints may be obtained from: E. Koskinen, Agricultural Research Centre, Equine Research, Varsanojantie 63, 32100 Ypäjä, Finland. E-mail: erkki.koskinen@mtt.fi, fax: +358 27602260. 